\title{
1921-1984 YILLARI ARASINDA YUGOSLAVYA'DA MUSTAFA KEMAL ATATÜRK HAKKINDA ÇIKAN ÇALIŞMALARIN BIBLIYOGRAFIK EKI*
}

\author{
Hazırlayan Mariyana TEODOSEVIÇ**. \\ Çeviren Zeynep ZAFER***
}

Yugoslavya'da Büyük Türk komutanı ve devlet adamı Mustafa Kemal Atatürk'e (1881-1938) gösterilen ilgi, Atatürk'ün Türkiye'nin bağımsızlığıyla ilgili başlattığı mücadele dönemine rastlar. Bizim kamuoyumuz bu mücadeleyi büyük bir sempatiyle takip ediyordu. Bu ilgi özellikle 29 Ekim 1923 yılında Türkiye Cumhuriyeti'nin ilan edilmesinden sonra büyüdü. Atatürk'ün devlet başkanlığına seçilmesiyle Türkiye ve ülkemiz arasında hem diplomatik, hem dostluk ilişkileri kuruldu.

Ekim 1930 yılında gerçekleşen Birinci Balkan Konferansı'ndan ve 1932 yılındaki İkinci Balkan Konferansı'ndan sonra, Türkiye ve Yugoslavya arasında yeniden bir yakınlaşma oldu. Özellikle Ekim 1933 yılında Kral Aleksandr'ın Türkiye'yi ziyaret etmesinden sonra bizim basınımızda Türkiye ve Kemal Atatürk'e ilgi yoğunlaştı. Türkiye'deki siyasi ve kültürel durum aynı zamanda Türkiye'nin kurucusu Atatürk konusunda kamuoyumuzu bilgilendirmek amacıyla ülkemizde yayınlar çıkmaya başladi.

Bibliyografyanın bu bölümünde Atatürk hakkında yazılan monografilerin yanısıra, Atatürk'ün hayatı ve faaliyetlerini ele alan eserler de yer almaktadir.

Bu çalışma, oldukça geniş sayılacak bir dönem içinde, yani 19211984 yılları arasında çıkan yayınları kapsamaktadır.****

\footnotetext{
* İSTORIYYSKİ ÇASOPIS (Tarihi Dergi), XLII-XLIII (1995-1996) str. 373-400.

** Belgrad Filoloji Fakültesi

*** A.U. DTCF Bulgar Dili ve Edebiyatı Anabilim Dalında Uzman (Çeviri Sırpça, Boşnakça, Hırvatca, Makedonca, Slovence'den yapılmíş̧ır).
} 


\section{KEMAL ATATÜRK'LE ILGILI YAZILAN VE KEMAL ATATÜRK’ÜN ADININ GEÇTIGĞI MONOGRAFILER}

\section{5}

\section{Lapçeviç, Dragişa}

O naşim muslimanima (Bizim Müslümanlar Hakkında): Sotsiyoloşke etnografske beleşke (Sosyolojik ve Etnografik Notlar)/Dragişa Lapçeviç, Beogrạd, knijarnitsa Gotse Koha 1925, 62 str*., ilustr**.

Kemal Atatürk Hakkında: s.61-62.

\section{1}

\section{Rayçeviç, Milorad}

Autografi znamenitih liçnosti XX veka (XX. Yüzyılın Önemli Otobiyografileri): 1910-1931/Izz zlatne knige Milorada Rayçeviça (Milorad Rayçeviç'in altın kitabından), Beograd, [s.l.], ${ }^{* * *}$ [s.a.],**** 12 str., ilustr. +58 str. autografa).

Müellif' in Atatürkle Görüşmesi, s.11-12'de bulunan otobiyografiler arasında Kemal Atatürk'ün otobiyografisi de bulunmaktadır.

\section{Svara, Maksim}

Gazi Mustafa Kemal-Paşa: Nyegov jivot i dyela (O'nun Hayatı ve Yaptıkları)/Maksim Svara, Sarayevo, İslamska Dioniçka Ştampariya 1931, 111 str., ilustr.

1932

\section{Raitçeviç, Milorad}

Les Autographes des Personnes İllustres du XX Siècle: 1910-1933/ De Livre doré du Milorade Raitchevitch. - Beograd: Sloga, [s.a.], -4, 16 str.: ilustr. + [67] str. autografa.

O autorovom sustretu sa Atturkom na engleskom yeziku (Müellifin İngilizce olarak Atatürkle Yaptığı Görüßsmesi), str.3-4, Takoce na frantsuskom yeziku (Fransızca Olarak Yaptığı Görüş̧e), str.14-16, Otobiyografileri arasında Kemal Atatürk'ün otobiyografisi de bulunuyor.

\section{Sfortsa, Grof Karlo}

Neimari savremene Evrope (Çağdaş Avrupa'nın Gözdeleri)/Grof Karlo Sfortsa, prevod (çeviren) îliya Kestsmanoviç, Zagreb, Kosmos 1932, 335 str., Mustafa Kemal, diktator realist (Mustafa Kemal Diktatör Realist), str. 293-312.

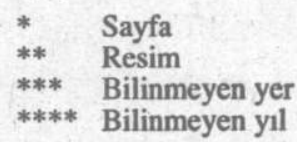




\section{Simiç, Stevan}

Nayveçi reformator sadaşnitse (Günümüzün En Büyük Yenilikçisi)/ Stevan Simiç, Skopiye, "Nemanya" zadujbinska ştampariya Vardarske banovine, 1932, 14 str.

\section{Topaloviç, Jivko}

Turska (Türkiye)/Jivko Topaloviç, Belgrad, İzdavaçka knijarnitsa Getse Kona, 1932, 88 str., ilustr.

Yeni Türkiye'nin Hareket Güçleri; s.44-59.

1934

\section{Dimitriyeviç, Haci Todor}

Spomenitsao tragiçnoy smırti viteşkog Kralya Aleskandra I Uyedinitelya (Birleştirici I. Kral Aleksandır'ın Trajik Ölümü Hakkında Bir Hatıra)/Haci Todor Dimitriyeviç, Beograd, Ştamparya "Privredni Pregled" 1934, 104 str., ilustr.

Kemalpaşa'nın Belgrad'taki Temsilcisi, s.47.

Türkiye; Gazi Mustafa Kemalpaşa'nın Telegrafi, s.83.

\section{Kruly, Uroş}

Senatski govori (Senato Konuşmaları)/Uroş Kruly, Beograd, Knyijara S. B. Tsviyanoviça, 1934, 62 str.

Balkan Antlaşması ve Türkiye'yle İmzalanan Uzlaşma, s.38-51.

\section{Radosavlyeviç, $M$.}

Nayviçi neimari Yugoslaviye (Yugoslavya'nın en Önemli Gözdeleri), Osnivaç, Oslobodilats, Uyedinitel (Kurucu, Kurtarıcı, Birleştirici), İlustrovana spomenitsa tragiçnih oktobarskih dogacaya (Trajik Ekim Olaylarının Resimli Anlıtı)/M. Radosavleyeviç, Beograd, Grafiçki umetniçki zavod "Planeta", 1943, 112 str., ilustr.

Kemal Atatürk Hakkında s.33-34.

11. Reçi Viteşkog Kralya Aleksandra I Uyedinitelya (Kahraman Birleştirici Kral I. Aleksandır'ın Sözleri)/Uredili i izdali R. Parejanin i B. Gavriloviç, Beograd, Ştampariya Minerva, 1934, 112 str, ilustr.

Kemal Atatürk Hakkında s. 105, 107.

1935

\section{Illustrovani List Nedelya}

İlustrovani List Nedelya, Spetsialni broy (Özel Sayı), Nova Turská (Yeni Türkiye), Beograd, 16; 428 (1935), 50 str. 
13. Naşa yavnost o Kralyu Muçeniku (Mazlum Kral Hakkında Geniş Kitlenin Görüşü) Priredili za ştampu (basına hazırlayan) Dinko Sirovitsa i Yurayı Kaliniç, Zagreb, İzdaniye zaklade tiskare Narodnih novina, 1935, 630 str., ilustr.

Kemal Atatürk Hakkında s.270, 366 .

14. Viteşki Kral Aleksandır I Uyedinitely/(hazırlayan) Sredio Milevoy Kazimir, Beograd, 1935.

Kemal Atatürk Hakkında, s.493.

15. Viteşki kraly Uyadiniteli u narodu. (Kahraman Birleștirici Kral, Halkın Arasındadır)/Sakupio i obradio za omladinu i narod (toplayan ve hazırlayan) Stiyepan Rotsa, Split, İzdaniye yugosilevenskog uçitelyuskog udrujineyi sektsiye za primorsku banovinu, 1935, 143 str., ilustr. Türkler, s.142-143.

\section{Mulaliç, Mustafa A.}

Oriyent na Zapadu (Batıdaki Şark), Savremeni kulturni i sotsialni problemi Muslumana Yugoslovena (Yugoslavya Müslümanlarının Çağdaş Kültürel ve Sosyal Problemleri)/Mustafa A. Mulaliç, Beograd, Ştamparya "Grafiçki institut" knyijare "Skerliç", 1936, 471 str., ilustr.

Kemalizm (Türkiye ve İran'daki Külttürel Yenileşmeye Tarihi Bakış), 431-460 s.

\section{Bey, Esad}

Alah ye velik: Propodanye i novi polet İslama od Abdulhamida do İbn Sauda (Allah Büyüktüre Abdül Hamit'ten İbn Saud'a kadar İslâmın Çöküşü ca Yeniden Parlaması/)Esat Bey, Preveo (çeviren) Manoylo Ozeroviç, Beograd, İzdavaçko i knijarsko preduzeçe Getse Kona, 1937, 480 str.

Genç General Anadolu'yu Uyandırıyor, s.206-218.

Sakarya'daki Mucize, s.233-249.

Mustafa Kemal Asya'dan Ayriliyor, s.249-264.

\section{Gocevats, Anka}

Amsterdam Ankara/Anka Gocevats, Beograd, İzdavaçka knijara Getse Kona, 1937, 117 str. 
Yeni Türkiye ve Kemal, s.59-75.

\section{Messner-Sporşiç, Ante}

Ot Bukureşta do Ankare: Kritike iz Rumunyske, Bugarske i Turske (Büküreş'ten Ankara'ya: Romanya, Bulgaristan ve Türkiye'den Notlar)/ Ante Messner-Spoşiç, Zagreb, Tipografiya, 1837, 242 str.

Türkiye ve Atatürk Hakkında s.122-242.

\section{Mihayloviç, Dragoslav P.}

Privreda Savremene Turske (Çağdaş Türkiye'nin Ziraatı)/Dragoslav P. Mihayloviç; Sa predgovorom Celala Bayara (Celâl Bayar'ın Yazdığı Önsöz ile), Beograd, Balkansi İnstitut, 1937, 8, 148, ilustr.

Kèmal Atatürk'ün Hayatı ve Yaptıklan, s.1-4.

\section{Amstrong, H.Ts.}

Kemal Paşa: Sivi vuk (Kemal Paşa: Bozkurt)/H. Ts. Amstrong, Sa predgovorom i pogovorom prevodiotsa (Çevirmenin Önsözü ve Yorumuyla), Btoro İzdaniye, Beograd, "Narodna kultura", İnstitut za natsionalnu prosvetu Yovana R. Şaranoviça, 1938, 33; 448 str.

\section{Svetovski, $M$.}

Ataturkova Turska (Atatürk'ün Türkiye'si)/M. Svetovski, Beograd, izdanye Balkanskog instituta, 1938, 226 str. (Biblioteka "Balkan i Balkantsi".

Asker-Kemal, s.57-82.

Devrimci-Kamal, s.83-135.

Yülkenin Atas1-Kemal, s.136-154.

1939

\section{Bulbuloviç, Edhem $N$.}

Turtsi i razvitak turske drjave sa uvodom u kulturnu i politiçku poviyest islama (İslâmın Kültür ve Siyasi Anlatımından Oluşan Girişle Türkler ve Türk Devletinin Gelişmesi)/Ethem N. Bulbuloviç, Sarayevo, Ştampariya "Bosanska poşta", 1939, 239 str., ilustr. 

212.

Kemalist Devrimi-Devrimin karakteri, faktörleri, stratejisi s.207232.

Kemalizm-Propaganda-Kemalizmin Eleştiri ve Savunması, s.212-

Ölüm İlânı, s.236-237.

24. Dardaneli i borba za Sredozemno more (Çanakkale Boğazı ve Akdeniz İçin Savaş), Beograd, İzdanye Sedme Sile, 1939, 64 str. (Dokumenti sadaşnyitse:11).

Kemal Atatürk hakkında s.5-27.

\section{Kus-Nikolayev, Mirko}

Kamal Atatürk: Ogled to turskom çudu (Kemal Atatürk: Türk Mucizesine Bakış), Mirko Kus Nikolayev, Zagreb, Nakladna knijara "Orbis", 1939, 30 str. (Biblioteka likovi).

\section{6. Şahınov-Ekremov, Munir}

Turska-Danis i Syutra: Prosyek kroz jivot yedne drjave (TürkiyeBugün ve Yarın: Bir Devletin Hayat Ortalaması)/Munir ŞahinovEkremov, Sarayevo, Muslimanske sviyest, 1939, 192 str., ilustr.

Kemal, Bir Dehanın Hayat Yolu, s.13-78.

\section{Tomiç, Zoran Sv.}

Kemal Ataturk. Tvorats nove Torske (Kemal Atatürk: Yeni Türkiye'nin Kurucusu)/Zoran Sv. Tomiç: Sa uvodom Suphi Tanriera (Tanrier'in yazdığı giriş) Beograd, Grafiçki umetniçki zavod "Planeta", 1939, $105 ; 287$ str, ilustr.

\section{[1939]}

\section{Hadzon, G.F.}

Turska, Grçka i istoçno Sredozemno more (Türkiye, Yunanistan ve Doğu Akdeniz)/G.F. Hadzon, Beograd, İzdavaçka zadruga politika i druştvo S.O. Y., 1939, 34 str. (Savremena pitanya: Posebna izdanya: Prevodi).

Kemal Atatürk'ün Savaşları s.21-24.

\section{4}

\section{9. Çontic, Mithat}

Turska i nyen polojay u svetu: İstoriski put turskog naroda: Privredni nazvitak: Politiçki jivot: Mecunarodni polojay (Türkiye ve O'nun Dünya- 
daki Yeri; Türk Halkının Tarihi Yolu; Ziraat Gelişmesi; Siyasi Hayatı ve Uluslararası Durumu)/Mithat Çontic, Beograd, Narodna kniga, 1954, 79 str.

Mustafa Kemal, s.15-18.

Reformların Uygulanması, s.26-28.

Cumhuriyet Düşmanlarına Karşı Mücadeleler s.28-29.

Bozkurt, s.29-30.

[1954]

30. Savremena Turska (Çağdaş Türkiye), Beograd, Novinsko izdavaçko predozeçe Udrujenya novinara Sırbiye, (s.a.), 157 str., ilustr.

Kemal Atatürk'ün Yaptıkları; Anadolu-Fırtınalı Geçmişin Ülkesi/ Mithat Çontic s. 35-37

Türk Halkının Karar Verme Saatlerinde Kemal/V. Sinceliç, s.43-45. s.45-48.

Türkiye'de Eski Kalıntılar ve Kemal Atatürk/Duşan Timotiyeviç

\section{0}

\section{Stoyadinoviç, Milan M.}

Ni rat ni pakt: Yugoslaviya izmecu dva rata (Ne Savaş Ne Antlaşma: İki Dünya Savaşı Sırasında Yugoslaviya)/Milan M. Stoyadinoviç, Riyeka, Otokar Kerşovani, 1970, 36; 679 str.

Kemal Atatürk'le Beraber, s.384-396.

\section{5}

\section{Dimitrovski-Takets, Dimitar}

Manaki i Bitola (Manaki ve Manastır)/Dimitar Dimitrovski-Takets, Bitola, Rabotniçkiot Uneverzitet “Krste P. Misirkov), 1975.

Atatürk ve Karinte.

\section{ARAŞTIRMALAR VE MAKALELER} 1921

1. İstoçno pitanye (Doğu Sorunu) - M. Spalaykoviç 
U:*

NOVİ JivOT, 5, 10 (25.06.1921) str. 289-295

2. Ratne operetsiye u Maloy Aziyi u yunu i yulu ove godine (Haziran ve Temmuz Yilında Anadolu'daki Savaş Operasyonları)/V.D.

U:

RATNIK, 37, 10, (oktobar /Ekim 1921) str. 78-85

3. Razliçitosti. Ratne operetsiye u Maloy Aziyi 1920-1921 (Farkl1liklar; 1920-1921 Yılında Anadolu'da Savaş Operasyonları)/V.D.

$\mathrm{U}:$

RATNIK; 37, 4-5 (April-May/Nisan-Mayis 1921) str. 191-194

$$
1922
$$

4. Yunak Turske Mustafa Kemal (Türkiye'nin Kahramanı Mustafa Kemal)/Abdurrezak Hifziya Byelovats

$\mathrm{U}:$

İRŞAD; 1,2 (1922) na str. 1.

5. Jivi Mrtvast (Ölümsüz) / Sakib Korkut.

$\mathrm{U}:$

İRŞAD; 1,3 (1922), str. 1-2.

1923

6. Kemal Paşa/Claire Price, preveo (çeviren) A.K.

U:

HIRVATSKA SLOGA: 5 (1923), str. 2-9.

Preuzeto iz ameriçke reviye "Current History" (Amerikan dergisi "Current History" den alınmıştır). $\mathrm{mu}) / \mathrm{N}$.

7. Unutraşni politiçki polojay Turske (Türkiye'nin İç Siyasi Duru-

* Makalenin yayımlandığı gazete veya derginin içinde bulunduğunu göstermektedir. 
$\mathrm{U}:$

NOVİ JiVOT; 13, 8, (14.04.1923), str. 230-231.

8. Ustavne problem u Turskoy (Türkiye'de Anayasa Sorunu)/N.Y.

$\mathrm{U}$ :

NOV JiVOT; 15, 11 (20.10.1923), str. 324-327.

9. Turska i mir na istoku (Turkiye ve Doğudaki Barış) / M. Pilya

$\mathrm{U:}$

NOVİ JivOT; 13, 6, (31.03.1923) str. 161-166.

10. Posle proglasa Turske Republike (Türkiye Cumhuriyeti'nin Ilanından Sonra)

U:

NOVİ JivOT: 16,3 (17.11.1923), str. 79-83.

11. Kemal-paşina vlada protiv radniçkih organizatsiya (Kemalpaşa Hükümeti İşçi Kuruluşlarına Karşı)

U:

RADNIÇKO YEDİNSTVO, 2, 16 (1923), str. 2-3.

\section{6}

12. Mlada Turska Republika: İzlaganye g. Yusufa Hikmeta o Kemalovim reformama (Yeni Türkiye Cumhuriyeti, Yusuf Hikmet Beyin Mustafa Kemal reformlan ile ilgili sunuşu)

U:

REÇ İ SLİKA; 1 ,2 (februar/Şubat/1926), str. 31-33, 160, ilustr.

13. Kemalova reforma i İslam na Balkanu: İstsırpliva ameriçka kniga o modernoy Turskoy (Kamal'ın Reformu ve Balkanlar'daki İslam; Modern Türkiye Hakkında yazılan bir Amerikan eseri)/Milan Şufflay

U:

NOVOSTİ: 20, 140 (1926), na str. 12. 
14. Yedan pogled na turske protuislamske reforme (Türk-İslâm Karşıtı Reformlara Bir Bakış)/Chameran [İbrahim Hakki Çokiç]

$\mathrm{U}$ :

HIIKYMET; 1, 4 (1929), str. 116-119.

1,5 (1929), str. 142-146.

1,6 (1929), str. 178-182.

1,8-9 (1929), str. 260-262.

1,10-11 (1929), str. 314-320.

2,15 (1930) str. 81-89.

15. Nayveçe dyelo Kemal-paşe: İnteresatna izyava Sveuçilişnog profesora za zapadno knyijevnost Yusufa Şerifa/S tuskog preveo Tahir Daudbegoviç (Kemalpaşa'nın En Önemli Eseri; Batı edebiyatı Profesörü Yusuf Şeref' in ilginç beyanatı, Türkçeden çeviren Tahir Daudbegoviç)

$\mathrm{U:}$

YUGOSLAVENSKİ LIST; 30,159 (1929), na str. 3.

\section{0}

16. Nova Turska/Osman Nuri Haciç (Yeni Türkiye)

$\mathrm{U:}$

GAYRET: 11,5 (1.03.1930), str. 73-75.

17. Kako stoi kemalistikçki rejim u Turskoy (Türkiye'deki Kemalist Rejim Nasil Ayakta Duruyor)

U:

HIKKYMET: 2,17 (1930), str. 155-158.

2,18 (1930), na str. 190.

18. Kroz hareme sultana i paşa (Sultan ve Paşaların Haremleri)

U:

ILOSTROVANI LIST NEDELYA; 12, 205 (15.02.1931), str. 16-18. 


\section{2}

19. Kemalizm i islamski sviyet/Avni (İslâm Dünyası ve Kemalizm)

U:

HIKKYMET: 3, 35 (1932), str. 150-152.

20. Kemal Paşa-İslam/Abdurahman Meşiç

U:

NOVI BEHAR, 6, 7-8 (1932-1933), str. 94-95.

21. A. Kemal-paşa i mi (A. Kemalpaşa ve Biz)/Nuriya Paşiç (A. Kemal Paşa ve Biz)

U:

NOVİ BEHAR: 6, 4-5 (1932-1933), str. 52-54.

22. Kemal-paşa i sviyet/Maksim Svara (Kemalpaşa ve Dünya)

$\mathrm{U}$ :

NOVI BEHAR, 6, 6(1932-1933), str. 74-75.

23. Simiç Stevan: Nayveçi reformator danaşnitse/A. Uroşeviç (Simiç Stevan; Günümüzün En Büyük Reformcusu)

U:

YUJNI PREGLED; 7, 11-12 (1932), na str. 489.

\section{3}

24. Preobrajenya yednog naroda (Bir Ulusun Değişmesi)/Hifzi A. Byelovats

U:

JivOT İ RAD; 17, 104 (15.12.1933), str. 1480-1490. .

25. Reforme Mustafe Kemal Paşe i nyihov znaçay u jivotu musulmana (Mustafa Kemalpaşa'nın Reformlan ve Bu Reformların Müslümanların Hayatındaki Önemi)/A. Byelovats

$\boldsymbol{U}:$

JivOT İ RAD; 17, str. 1291-1301. 
26. İz turskog sviyeta (Türk Dünyasından) Chameran/[İbrahim Hakki Çokiç]

U:

HİKYMET; 4, 45 (1933), str. 285-288.

27. Deset godina nove Turske: İstoriyska syednitsa Turske narodne skupştine (Yeni Türkiye'nin Onuncu Yıldönümü; Türkiye Millet Meclisinin Tarihi Oturumu)

U:

YUOGSLOVENSKA POŞTA; 5, 1339 (16.10.1933) na str. 6.

28. İz turskog sviyeta (Türk Dünyasından)/H.

$\mathrm{U}$

HİKYMET; 5, 54 (1933) str 190-192.

5,55 (1934) str. 222-224.

29. Nova Turçiya: Deset let konstruktivnega dela (Yeni Türkiye; Yaratıcılığın Onuncu Yıldönümü)/Ali Bey Haydar, Priopçio (iştirak eden) S.M.

U:

SLOVENSKI BEOGRADSKI TYEDNIK; 1, 4 (1933), str. 1-2.

30. "Yugoslovenska poşta" na proslavi 10-godişnitse Kemalove Turske: Novi jivot na ruşevinama Otomanskog tsarstva ("Yugoslavenska poşta", Kemal Türkiye'sinin Onuncu Yıldönümünde; Osmanlı İmparatorluğu'nun Yıkıntılarında Yeni Bir Hayat)/Hamza Humo

U:

YUGOSLAVENSKA POŞTA, 5, 1354 (1933), na str. 9.

5, 1358 (1933), na str. 6.

5,1360 (1933), na str. 9.

5, 1363 (1933), na str. 6 .

5, 1364 (1933), na str. 6. 
31. Kemalistıçke vyerske reforme: Odgovor Milyku Karaçu i nyegovim istomişlinitsima (Dini Kemalist Reformlar: Milyko Karaç ve onun gibi düşünenlere cevap)/Yahyazade

U.

HİKYMET; 4, 46 (1933), str. 312-314.

32. Deset godina nove Turske: Kemalpaşa stvara Tursku Republiku: Lozanski mir pırva pobiyeda Aziye nad noviyom Evropo (Yeni Türkiye'nin Onuncu Yıldönümü; Kemalpaşa Türkiye Cumhuriyeti'nin Kuruyor, Lozan Barış Antlaşması Asya'nın Yeni Avrupa'ya Karşı İlk Zaferi)

U:

YUGOSLOVENSKA POŞTA; 5, 1336 (21.10.1933), na str. 9.

33. Turski politçki krugovi oçekuyu de çe sastanak u Tsarifgradu uçvrstiti politiku mira, poverenya i saradnye na Balkanu: Sastanak Ny. V. Kralya sa predsednikom Turske Republike: Doçek Ny. V. Kralya i Kralyitse u Tsarigradu ye veoma srdaçan (Türk Siyasi Çevreleri İstanbul'daki Toplantının Balkanlarla Olan Barıs Siyasetini, Güveni ve İşbirliğini Kuvvetlendireceğine Ümit Ediyorlar; Kralya Ny. V.'nın Türkiye Cumhuriyeti Devleti Başkanıyla Görüşmesi; Kralya Ny. V. ve Kralyiçe İstanbul'da Çok Sıcak Karşılandılar).

U:

POLITIKA: $30,9121(5.10 .1933)$ na str.1.

34. U Tsarigradu Turski politiçki kurgovi oçekuyu Balkanski Sporuzum: posle sastanka u Tsarifgradu: Ny. V. Kralya i Kralyitsa stiju "Dubrovnikom" pred Kırf, a na ostırvo çe se iskırtsati sutra uyutro (İstanbul'daki Siyasi Cevreler Balkan Devletleri Antlaşmasını Bekliyorlar; İstanbul'daki Toplantıdan Sonra Kral Ny. V. ve Kraliçe "Dubrovnik"le ve Korfi Adasına Ulaştılar)/Mihaylo Petroviç

U:

- POLITIKA; 30, 9122 (6.10.1933), na str.1. diri)

35. Zvaniçno 'saopştenye o sastanku (Toplantı Hakkında Resmi Bil-

$\mathrm{U}:$

POLITTIKA; 30.9122, (6.10.1933), na str.1. 
36. Veçera kod Gazi Mustafe Kemal-paşe (Gazi Mustafa Kemalpaşa'da Akşam Yemeği)

$\mathrm{U}:$

POLİTIKA; 30,9122, (6.10.1933), na str.1.

37. "Dubrovnik" ye yuçe uyutro krenuo za Korfi ("Dubrovnik" Dün Kırf Adası'na Doğru Hareket Etti)

POLİTiKA; $30,9122(6.10 .1933)$, na str.1.

38. Otkada Mustafa Kemal nosi titulu Gazi i şta ona znaçi Da li znate? (Mustafa Kemal Ne Zamandan Beri Gâzi Unvanına Sahiptir ve Bu Unvanın Anlamı Nedir, Biliyor musunuz?)

U:

POLITIKKA: $30,9122,(6.10 .1933)$, na str. 11.

39. Politiçka aktivnost nove Turske: Rezultati koyi se oçekuyu ot puta Ny. V. Kralya (Yeni Türkiye'nin Siyasi Faaliyetleri; Ny. V. Kralın Yolculuğundan Beklenilen Neticeler)/Mih. Petroviç.

POLİTIKA; 30, 9130 (14.10.1933), na str. 1.

40. Şest printsipa Turske Republike. Republikanizam, natsionalizam, demokratiya, laitsizam, dırjavotvorstvo, revolutsionarstvo: Pred proslavu u Ankari (Türkiye Cumhuriyeti'nin Altı Prensibi; Cumhuriyetçilik, Milliyetçilik, Demokrasi, Lâiklik, Devletçilik, Inkılâpçılık; Ankara'daki Törenden Önce)/M. S. Petroviç.

U:

POLİTIKA; 30, 9140 (14.10.1933), str. 1-2.

41. Stara i nova Ankara: Povodom proslave Turske Republike: Prestonitsa koya ye za deset godina izrasla iz puste (Eski ve Yeni Ankara: Türkiye Cumhuriyeti'nin Onuncu Y1l Dönümünün Kutlamaları Sebebiyle; Çölde Kurulan Onyıllık Başkent)/M.S. Petroviç

U:

POLİTiKA; 30, 9144 (28.10.1933), na str. 5.

42. Turska Republika danas proslavlya svoyu desetgodişnitsu (Türkiye Cumhuriyeti Bugün Onuncu Yll Dönümünü Kutluyor)/T.

U: 
POLITIKA; 30, 9145 (29.10.1933), na str. 2.

43. Kemal-paşa drji govor masi od preko 100.000 lyudi: Proslava desetogodinhyitse Turske Republike (Kemalpaşa 100.000 Kişi Önünde Konuşma Yapıyor; Türkiye Cumhuriyeti'nin Onuncu Yıl Dönümü Kutlamalari)

U:

POLITIKA: 30, 9147, (31.10.1933), na str.3.

44. G. Alber Saro o novoy Turskoy (G. Alber Saro Yeni Türkiye Hakkında)

U:

POLITIKA; 30, 9147 (31.10.1933), na str. 3.

45. T urska Republika i turska voyska: Posle Ankarskih sveçanosti: Yako se u Turskoy sve ostalo iz osnova izmenilo voyska ye ostala glavni faktor u drjavi (Türkiye Cumhuriyeti ve Türk Ordusu; Ankara Kutlamalarından Sonra; Türkiye'de Her Şey Yeniden Değişime Uğrasa da Ordu Devletin En Önemli Faktörü Olarak Kaldı)/M.S. Petroviç

U:

POLITIKA; 30, 9156 (9.11.1933), na str. 2.

46. Kemalisti i islamska verska zayednitsa: Pismo iz Turke: Zaşto ye Kemal Paşa odvoyio veru ot drjave (Kemalistler ve Diyanet İşleri, Türkiye'den Mektup: Kemalpaşa Dini Neden Devletten Ayırdı)/M.S. Petroviç

$\mathrm{U}:$

POLITIKA; 30, 9160 (13.11.1933), na str. 6-7.

47. Danaşnyi pakt priyatelstva sa Turkom pripremlyen ye yoş pre11 godina: Odbiyanyem da uçastvuye u pododu na Tsarigrad, naşa drjava ye omoguçila konsolidovanye Turske (Türkiye ile Olan Barış Antlaşması 11 Yıl Once Hazırlanmıştı, İstanbul'a Olan Sefere Katılmayı Rededen Devletimiz Türkiye ile İlişkilerini Sağlamlaştırmıştır)/Andra Milosavlyeviç 
U:

POLİTiKA; 30, 9174 (27.11.1933), na str.1. noviç

48. Yugoslavya i Turska (Yugoslavya ve Türkiye)/Nacib Abduramo-

U:

POLITİKA; 30, 9176, (29.11.1933), na str. 2.

49. Mustafa Kemal

U:

NARODNE NOVINE; 37 (1933), str.2-3.

50. 10-godişnitsa Turske Republike: Mustafa Kemal utvrduye vlast (Türkiye Cumhuriyeti'nin Onuncu Yıl Dönümü; Mustafa Kemal İktidarı Tasdik Ediyor)

U:

YUGOSLOVENSKA POŞTA; 5, 1340 (27.10.1933) na str. 3.

51. Neimari savremene Evrope (Çağdaş Avrupa'nın Gözdeleri) / Karlo Sfortsa, Prikaz Milan Rayiç (anlatan Milan Rayiç)

U:

JivOT İ RAD; 14, 83 (1.02.1933), str. 137-146.

52. Deset godina Turske Republike (Türkiye Cumhuriyeti'nin Onuncu Yıldönümü)/Maksim Svara

U:

NOVİ BEHAR; 7, 8-9-10 (15:11.1933), str.120-122.

1934

53. Yugoslaviya ye izgubila svoga, velikog voçu, a çoveçanstva nayiveçeg pristalitsu mira (Yugoslavya Büyük Önderini, Dünya İse En Büyük Barışçısını Kaybetti)/ D.P. Mihayloviç 
$\mathrm{U:}$

POLITIKA; 31, 9483 (11.10.1934), na str. (6).

54. Telegram Gazi Kemal Mustafa-paşe (Gazi Mustafa Kemalpaşa'nın Gönderdiği Telgraf)

$\mathrm{U}:$

POLITIKA; 9483 (11.10.1934), na str. [14]

55. Zvaniçne delegatsiye stranih drjava na pogrebu; Turska delegatsiya (Yebancı Yülkelerin Resmi Heyetleri Cenaze Töreninde; Türkiye'nin Heyeti)

$\mathrm{U}$ :

POLITIKA; 31,9488 (16.10.1934), na str. [11].

56. 29. Oktobar natsionalni praznik Turske: Uspesi mirolyubive politike Gazi Mustafa Kemal Passe (29 Ekim, Türkiye'nin Milli Bayramı, Gazi Mustafa Kemalpaşa'nın Barışçı Politikasının Başarıları)

$\mathrm{U}$ :

POLITIKA; 31, 9501 (29.10.1934), na str. 2.

57. Yevtiç u spesiyalnoy audiyentsiyi kod Kemal-paşe: Turska ştampa o ubrzavaniyu protsesa urganizatsiye mira na Balkanu (Yevtıç, Kemalpaşa'nın Özel Kabulu Sırasında: Balkanlar'daki Barış Sürecinin Oluşma Organizasyonuyla İlgili Türk Yayınları)

$\mathrm{U:}$

YUGOSLOVENSKA POŞTA; 5, 1485 (21.04.1934), na str. 1.

\section{5}

58. "Kemal" Ataturk a ne "Kiyemal" ("Kiemal" Değil "Kemal" Atatürk)/Muhsin Ebul

$\mathrm{U}$ :

HİKYMET; 6,3 (1935), str.93-94.

59. Posveçeno Velikom i Heroyiskom Pretsyedniku Turske Republike Bay Kemalu Ataturku (Türkiye Cumhuriyeti'nin Büyük ve Kahraman Başkanı Bay Kemal Atatürk'ke Adanmıştır)/Şirin Haydin). 
U:

NEDELYA; 16, 428 (1935), na str. 25.

60. Kemalpaşa o balkanskom Sporazumu: Balkanske zemlye nastaviça yoş intenzivniye politiku saradnye i mejusobne pomoçi (Kemalpaşa, Balkan Antlaşmasıyla İlgili; Balkan Ülkeleri, Siyasal İşbirliğini ve Yardımlaşmayı Daha Yoğun Bir Şekilde Devam Edecektir)

U:

YUGOSLOVENSKA POŞTA; 6, 1804 (11.05.1935), na str.1.

61. Velik ye Kemal Ataturk (Kemal Atatürk Büyüktür)/Spektator

$\mathrm{U}:$

DUBROVAÇKA TRUBUNA; 7, 276 (1935), na str. 1.

\section{6}

62. Od skopskog gimnazialka i lyekara do ministra inostranih dyela: Dr. Tefik Rüştü Aras: Jivot istaknutog saradnika stvaraoka Nove Turske Atatürka (Üsküp lisesinden doktorluğa ve dışişleri bakanlığına kadar. Dr. Tefik Rüştü Aras: Yeni Türkiye'nin yaratıcısı Atatürk'ün ünlü arkadaşının hayatı/Maksim Svara).

$\mathrm{U}:$

PRAVDA; 10, 43 (1936), str. 9-10.

63. Priyatelstvo Yugoslaviye i Turske treba sprovoditi i kroz srtsa jena i omladine (Yugoslavya ve Türkiye Arasındaki İyi İlişkileri, Bu Ülkelerin Kadınları ve Gençleri Arasında da Olmalıdırlar).

$\mathrm{U:}$

NEDELYNE ILUSTRATSIYE; 12,50 (13.12.1936), str. 6-7.

\section{7}

64. Kemalistiçka Turska i nyezin voca Gazi Mustafa Kemal-Ataturk (Kemalist Türkiye ve Onun Önderi Mustafa Kemal Atatürk)/Esadbeg Alibegoviç

U: 
GAYRET; 18, 12 (Oktober/Ekim 1937), na str. 214.

18, 14 (detsembar/Aralık 1937), na str. 262.

65. Otvaranye turske izlojbe u Muzeyu Kneza Pavla (Prens Pavle Müzesi'nde Türk Sergisinin Açılışı)/B.

U:

BEOGRADSKE OPŞTİNSKE NOVINE; 4-6 (april/-yuni/NisanHaziran 1937), str. 371-372.

66. Utistsi s kongresa u Dolmabahçi: Şef drjave Kamal Ataturk prisustvuvao ye svakoga dana i priye i posliye podne, syednitsama kongresa (Dolmabahçe'deki Kongreden İzlenimler; Devlet Başkanı Atatürk Ögleden Önce ve Öğleden Sonra Olmak Üzere Her Gün Kongrenin Oturumlarına katıldı)/ Fehim Bayraktareviç

$\mathrm{U:}$

GAYRET: 18, 14 (detsembar/Aralık 1937), str. 260-261)

67. Mustafa Kemal, nepriyately traditsiye (Mustafa Kemal, Geleneklerin Düşmanıdır)/Hans Froembgen.

U:

IZBOR NAYBOLYIH SAVREMENIH ÇLANAKA; 2, 9 (septembar/Eylül 1937), str. 960-965.

68. İzlojba turskih slika i publikatsiya (Türk Resim ve Yayını Sergisi), Beograd, Muzey Kneza Pavla (Prens Pavle Müzesi), 1937, str. 209, ilustr.

69. Kako yi postala Turska Republika? İz knyige Maksima Svare Gazi Mustafa Kemala-paşa (Türkiye Cumhuriyeti Nasıl Doğru?, Maksim Svare'nin "Gazi Mustafa Kemal Paşa" Kitabından).

U:

PRAVDA; 11, 43 (1937), na str. 4.

1938

70. Predsednik turske republike: Nikoya odlomkov iz nyegovih nayvajniyh govora (Türkiye Cumhuriyeti'nin Başkanı; O'nun En Önemli Konuşmalarından Bazı Alıntılar)/Havzi Byelovats. 
$\mathrm{U:}$

SLOVENATS; 66, 162 (1938), na str. 9.

71. Bolest g. Kemala Ataturka pogorşala se (Bay Kemal Atatürk'ün Sağlık Durumu Kötüleşti).

$\mathrm{U}$ :

POLİTIKA: 35, 10939 (10.11.1938), na str. 1.

72. Gazi Mustafa Kemal-paşa Ataturk/M[ilo] B[oroyeviç].

$\mathrm{U}:$

NOVII BENAR; 12, 7-14 (1938-39), str. 117-122.

73. G. Kemal Ataturk ponovo teşko oboleo (Bay Kemal Atatürk Yeniden Ağır Hastalandı)/C. Bukilitsa

$\mathrm{U}$ :

VREME, 18, 6038 (10.11.1938), na str.1.

74. Pripreme za pogreb Kemala Ataturka (Kemal Atatürk'ün Cenaze Töreni Hazırlanıyor)/C. Bukilitsa.

$\mathrm{U}$ :

VREME; 18, 6044 (16.11.1938), na str. 4.

75. Sahrana Ataturkova obaviçe se 21. novembra u Ankari (Atatürk'ün Cenaze Töreni 21 Kasımda Ankara'da Yapılacaktır)/C. Bukilitsa.

$\mathrm{U}$ :

VREME; 18, 6041 (13.11.1938), na str.3.

76. Smrt Kamala Ataturka (Kemal Atatürk'ün Ölümü)/C. Bukilitsa U:

VREME; $18,6039(11.11 .1938)$ na str. $1,4$.

77. Turska sprema grandiozan pogreb Ataturku (Türkiye, Atatürke Muhteşem Bir Cenaze Töreni Hazırlıyor)/C. Bukilitsa.

U: 
VREME; 18, 6043 (15.11.1938), na str. 3.

78. Zakletva studentske omladine pred Ataturkovim Pomenikom u Tsarigradu (İstanbul'da Bulunan Atatürk'ün Anıtı Önündeki Türk Üniversite Gençliği'nin Yemini)/C. Bukilitsa.

$\mathrm{U:}$

VREME; 18,6042 (14.11.1938), na str. 3.

79. Mustafa Kemal/Edhem Bulbuloviç.

YUGOSLOVENSKİ LİST; 21, 266 (11.11.1938), na str. 3.

80. Ataturkov pogreb (Atatürk'ün Cenazesi)/B. TS.

U:

VREME; 18, 6049 (21.11.1938), na str. 1,3.

81. Yuçe ye u Anvkari sahranyen kemal Ataturk (Dün Ankara'da Kemal Atatürk Defnedildi)/V.Ts.

U:

VREME; 18, 6050 (22.11.1938), na str.1,3.

82. Tsarigrad u jalosti: Slike naşeg spetsiyalnog dopisnika R. Noiveyea (İstanbul Yas Tutuyor; Özel Muhabirimiz R. Noiveyea'nın Yaptı̆̆ı Fotoğrafları)

U:

VREME; 18, 6041 (13.11.1938) na str.1.

83. Savremeni İslam (Çağdaş İslâm)/André Clot.

$\mathrm{U:}$

IZVOR NAYBOLYIH SAVREMENIH ÇLANAKA; 3,5 (Mayıs 1938), str. 518-539.

84. Politiçko izgracivanye nove Turske (Yeni Türkiye'nin Siyasi Yapılanması) Manoylo Çuçkovic

U:

YUJNI PREGLED; 12, 11-12 (novembar-detsembar/Kasım - Aralık 1938), str.430-440. 
85. Danas ye turski narod otpratio na veçni poçinak otsa Turske (Bugün Türk Milleti Türkiye'nin Babası Olan Kemal Atatürk'ü Ebedi İstirahatına Gönderdi).

U:

PRAVDA; 34, 12223 (22.11.1938), na str.1.

86. Gazi Mustafa Kemal Atatürk: Otats Nove Turske i Turaka kao nove generatsiye (Gazi Mustafa Kemal Atatürk, Yeni Türkiye'nin Yeni Türk Neslinin Atası).

U:

POLITIKA; 35, 10941 (12.11.1938), ha str. 2.

87. Iz jivota Kemala Ataturka: Na putu ka spasu i preporodu Turske (Kemal Atatürk'ün Hayatından; Türkiye'nin Kurtuluşu ve Yeniden Doğuşu).

U:

PRAVDA; 34, 12214 (13.11.1938), na str. 1-2.

88. Politiçki Pregled: Dva pokoynika (Siyasi Bakış; İki Rahmetli)/ İnostrani, yabancı (Yovan Yovanoviç-Pijon).

U:

SRPSKİ KNYEJEVNİ GLASNIK; ; 5, 7 (1.12.1938), str. 528-531.

89. Umro ye otak Turaka-Kamal Ataturk, veliki drjavnik, voynik i reformator (Türklerin Atası Büyük Devlet Adamı, Asker ve Yenilikçi Mustafa Kemal Vefat Etti)/İliya Yukiç.

U:

HRVATSKİ DNEVNIK; 3, 904 (1938), na str.2.

90. Kemal Ataturk na odru: fotografiye (Kemal Ataturk'ün Ölümü; fotoğraflar).

U:

VREME; 18, 6047 (19.11.1938), na str. 1.

91. Kemal Ataturk. 
U:

YUTRO; 19, 262 (1938), na str. 1.

92. Ankara se priprema za grandioznu sahranu Ataturka (Ankara Atatürk'ün Muhteşem Cenaze Töreni İçin Hazırlanıyor)/Lukaçeviç

$\mathrm{U}$ :

VREME; 18, 6047 (19.11.1938), na str. 3.

93. Danás Tsarigrad ispraça na veçni poçinak u Ankaru otsa Nove Turske Kemala Ataturka (Bugün İstanbul Yeni Türkiye'nin Atası Olan Atatürk'ü. Ankara'daki Ebedi İstirahatına Uğurlamaktadır)/M. M[arkoviç].

U:

POLITIKA; 35, 10948 (19.11.1938), na str. 5.

94. Danas Narodu u Tsarigradu poçinye da odaye poştu Kemalu Ataturku (Bugün İstanbul'daki Halk Kemal Atatürk'ü Saygı Duruşunda Bulunmaya Başladi) / M. Markoviç.

$\mathrm{U:}$

POLITIKA; 35, 10945 (16.11.1938), na str. 5.

95. Gazi Kemal Ataturk tvorets nove Turske, izdahnyo yuçeu dvortsu Dolma Bakçe u Tsarigradu (Dün Yeni Türkiye'nin Kurucusu Gazi Kemal Atatürk İstanbul'daki Dolma Bahçe Sarayı'nda Son Nefesini Verdi) / M. Markoviç

U:

POLITIKA; 35, 10940 (11.11.1938), na str. 1-2.

96. Kemal Ataturk biçe sahranyen u veliçanstveni mauzoley, koi çe se podiçi verovatno na negovyom imanyu kod Çankaya u bliznii Ankare (Kemal Atatürk Büyük Bir İhtimalle Ankara Yakınlarında Bulunan Çankaya Arazisininde İnşa Edilecek Olan Mozoleye Gömülecektir) / M. Markoviç

U:

POLITIKIKA; 35, 10944 (15.11.1938), str.1-2.

97. Posle smrti Kemala Ataturka za predsednika Turske Republike izabran ye g. İsmet İneni (Kemal Atatürk'ün Ölümünden Sonra Türkiye Cumhuriyeti'nin Başkanı Görevine İsmet İnönü Seçildi) / M. Markoviç. 
U:

POLİTIKA; 35, 10941 (12.11.1938), na str. 1.

98. Sveçana sahrana Kemala Ataturka obaviçe se u nedelyu, 21. novembra u Ankari (Kemal Atatürk'ün Cenaze Töreni 21 Kasım Pazar Günü Ankara'da Düzenlenecek)/M. Markoviç.

U:

POLİTIKA; 35, 10947 (18.11.1938), na str.3.

99. Turska plaçe nad odrom svoga tvortsa Kemala Ataturka (Türkiye, Kurucusu Kemal Atatük'ün Arkasından Gözyaşı Döküyor) / M. Markoviç.

$\mathrm{U}$ :

POLITIKA; 35, 10942 (13.11.1938) str. 1-2.

100. Turska ştampa u Ataturku (Atatürk'le İlgili Türk Yayınları) / M. M [arkoviç].

$\mathrm{U:}$

POLITIKIKA; 35, 10941 (12.11.1938), na str. 2.

101. Veliçanstvena sahrana Kemala Ataturka u Ankari (Ankara'da Kemal Atatürk'ün Muhteşem Cenaze Töreni) / M. Markoviç.

$\mathrm{U:}$

POLITIKA; 35, 10951 (22.11.1938), na str. 3 :

102. Jalost u Turskoy za Kemalom Ataturkom (Türkiye'nin Kemal Atatürk İçin Yas Var) / M. M. [arkoviç].

$\mathrm{U}$ :

POLITIKIKA; 35, 10954 (25.11.1938), na str. 3.

103. Na putu ka spasu i preporodu turske (Türkiye, Kurtuluşa ve Rönesansa Doğru).

$\mathrm{U:}$

PRAVDA; 34, 12213 (12.11.1938), str. 1-2. 
104. Natsionalna borba Kemala Ataturka (Kemal Atatürk'ün Milli Mücadelesi).

U:

PRAVDA; 34, 12211 (10.11.1938), na str.1.

105. Neuçekivano, stanye zdravlya pretsednika Turske Republike g. Ataturka ozbilyno se pogorşalo (Türkiye Cumhuriyeti'nin Başkanı Sayın Atatürk'ün Sağlık Durumu Aniden Kötüleşti)

U:

PRAVDA; 34, 12211 (10.11.1938), na str. 3.

106. Nepregledne mase odaya poslednyi poçast Kemalu Ataturku (Yoğun Halk Kitlesi Kemal Atatürk'e Son Saygı Borcunu Ödedi).

PRAVDA; 34, 12218 (17.11.1938), na str. 2.

107. O poslednim çasovima Ataturka: Opis liyeçnika Dr. Nihat Reşada (Atatürk'ün Son Saatleri; Dr. Nihat Reşat' in Anlattıkları)

$\mathrm{U:}$

YUGOSLOVENSKİ LIST; 21,289 (8.12.1938) na str. 3.

108. Gazi Mustafa Kemal Ataturk (1881-1938)/Tayib M. Okiç

U:

PREGLED; 12, 179-180 (1938), str. 776-779.

109. “Ataturkova Turska” od M. Svetovskog (Atatürk'ün Türkiye'si - M. Svetavskog'tan)/P.

U:

XX VEK ; 1,9 (novembar/Kasım 1938), na str. 623.

110. Kemala ye nestalo, ali negovye ideye ostayu za turski narod (Kemal Öldü Ancak O'nun Fikirleri Türk Halkında Kaldı) / N.P.

U:

PRAVDA; 34, 12213 (12.11.1938), str. 1-2.

111. Posliye Ataturkove smrti (Atatürk'ün Ölümünden Sonra)/A [ntun] P[ilepiç]. 
$\mathrm{U}:$ Z.Z.)

KATOLIÇKA RUYEÇ; 4, 46 (1938), na str. (sayfa yazılmamıştır.

112. Istoriyskil ik Kemala Ataturka (Kemal Atatürk'ün Tarihi Kişiliği)/Vasily Popoviç

U:

POLITIKA; 35, 10942 (13.11.1938), na str. 2.

113. Posle yuçeraşnyeg dirlyivog oproştaya nove Turske sa svoyim tvortsem danas ye turska omladina miting pred Etnografskim muzeyom, na kome se zavetovala da çe çuvatı natsionalne tekovine Kemala Ataturka (Dün Yeni Türkiye Kurucusundan Acıklı Bir Şekilde Ayrıldıktan Sonra, Bugün Türk Gençliği Etnografik Müzesi'nin Önünde Düzenlendiği Mitingte Kemal Atatürk'ün Bıraktığı Milli Mirası Koruyacaklarına Dair Söz Verdi).

U:

PRAVDA; 34, 12224 (23.11.1938) na str. 3.

114. Posledniy Dan Ataturkov u Tsarigradu (Atatürk'ün İstanbul'daki Son Günü).

U:

VREME; 18, $6046(18.11 .1938)$, na str. 3.

115. Posledniy povratak tvortsa nove Turske u Ankaru (Yeni Türkiye Kurucusunun Ankara'ya Son Yolculuğu).

U:

PRAVDA; 34, $12221(20.11 .1938)$, na str. 1.

116. Pred Parlamentom u Ankari veç ye gotov gigantski katafalk, na kome çe poçivati telo velikog tvortsa nove Turske (Yeni Türkiye Kurucusunun Naaşının Konulacağı Büyük Katafalk Ankara Parlamentosunun Önünde Hazırlandı).

$\mathrm{U}$ :

PRAVDA; 34, $12220(19.11 .1938)$ na str.2.

117. Preko predsednika Republike do obiçnog gracanina, u nepriglednom defileu, od yutros turski narod odaye poslednyu poştu velikom 
tvortsu svyoe nove otacbine (Türk Milletinin Tamamı Ülkenin Büyük Kurucusuna Son Saygı Görevini Yerine Getiriyor).

U:

PRAVDA; 34, 1222 (21.11.1938), na str. 3.

118. Prenos tela Kemala Ataturka iz Tsarigrada u Ankaru izvrşiçe se sa veliçanstvenim posmrtnim poçastima (Kemal Atatürk'ün Naaşı İstanbul'dan Ankara'ya Muhteşem Töreniyle Taşınmıştır)

$\mathrm{U}:$

PRAVDA, 34, 12214 (13.11.1938), na str. 1.

119. Preporoditely Turske Kemal Ataturk i nyegov naslednik İsmet İnönü (Türkiye'ni Yenilikçesi Kemal Atatürk ve O'nun Devamcısı İsmet İnönü)

$\mathrm{U}:$

PRAVDA; 12, 46 (Sarayevo, 1938), str. 9-11.

120. Preporocena Turska (Yeniden Doğan Türkiye)

U:

NEDELYNE ILUSTRATSIYY; 14, 8 (20.2.1938), str. 4-7.

121. Moy prvi susret sa Kemalom Ataturkom (Kemal Atatürk'le İlk Görüşmem)/Novitsa B. Rakoçevic

U:

POLITIKA: 35, $10946(17.11 .1938)$ na str. 4.

122. Slava Kemalu Ataturku (Kemal Atatürk'ün Ünü).

U:

VREME; 18,6039 (11.11.1938), na str. 3.

123. Smrt Kemala Ataturka izazvala ye veliku jalost u naşoy zemlyi (Kemal Atatürk'ün Ölümü Bizim Topraklarımızda da Büyük Ủzüntü Yaratt1).

$\mathrm{U}:$

PRAVDA; 34, 12212 (11.11.1938), na str. 2. 
124. Po prahu istoriye: Uvod u putopis (Tarihin Tozlarında; Gezi Notlarına Giriş)/M. Svetovski.

U:

XX.VEK; 1, 1, (yanuar/Ocak 1938) str. 127-130

125. Testament Kemala Ataturka: Srtse Ataturkovo biçe saçuvano u posebnoy urni (Kemal Atatürk'ün Vasiyetnamesi; Kemal Atatürk'ün Kalbi Özel Bir Sandıkta Korunacaktır)

U:

YUGOSLOVENSKA POŞTA; 10, 2880 (16.11.1938), na str.1.

126. Turski narod defiluye pored odra svoga slavnog preporoditelya i voca: Smrt Kemala Ataturka izazvola ye veliku jalost u svim drjavama saveznitsama Turske (Türk Halkı Önderlerine Saygı Duruşunda Buyunuyor; Kemal Atatürk'ün Ölümü Türkiye'nin Müttefik Ülkelerinde Büyük Üzüntü Yarattı).

U:

PRAVDA; 34, 12213 (12.11.1938), na str 1.

127. Turski narod se klanya svome velikom preporoditelyu (Türk Halkı Büyük Önderlerinin Önünde Büyük Saygıyla Eğiliyor).

U:

PRAVDA; 34, 12215 (14.11.1938), str. 1-2.

128. U Ankari se danas sahranyuye otats Nove Turske, Kemal Ataturk (Yeni Türkiye'nin Atası Kemal Atatürk Bugün Ankara'da Toprağa Veriliyor),

U:

POLITIKA, 35, 10950 (21.11.1938), na str. 2.

129. Velikim pogrebnim poçastima Kemalu Ataturku u Ankari prisustvuvaçe voyniçki odredi sedam drjava pored spetsiyalnih deligatsiya (Ankara'da Kemal Atarürk'ün Cenaze Törenine Özel Heyetlerin Dışında Yedi Devletten Askeri Temsilcileri de Katıldı).

U:

PRAVDA; 34, 12219 (18.11.1.938), na str. 1-2.

130. Veliki şef Turske Republike Kemal Ataturk preminuyo yutros (Türkiye Cumhuriyeti'nin Büyük Önderi Dün Sabah Vefat Etti). 
U:

PRAVDA; 34, $12212(11.11 .1938)$ na str. 1.

131. Voyak revolutsionar in preporoditely: $\mathrm{Ob}$ mrtvaşkom odru $\mathrm{Ke}-$ mala Ataturka, ustvaritelya Nove Turçiye (Asker, İhtilâlci ve Yenilikçi; Yeni Türkiye'nin Kurucusu Kemal Atatürk'ün Ölümüne Dair).

U:

YUTRO; 19, 265 (1938), na str. 6.

132. Jivot i Delo kemala Ataturka (Kemal Atatürk'ün Hayatı ve Eserleri)

U:

POLITIKIKA; 35, 10940 (11.11.1938) na str. 2.

133. Jivot i rad Kemala Ataturka, tvortsa moderne Turske (Modern Türkiye'nin Kurucusu Kemal Atatürk'ün Hayatı ve Faaliyetleri).

U:

VREME; 18,6039 (11.11.1938), str. 3-4.

134. Jivot Kemala Ataturka (Kemal Atatürk'ün Hayatı).

U:

PRAVDA; 34, 12212 (11.11.1938) str. 1-2.

135. Smrt Kemala Ataturka: Proklamatsiya vlade turskom narodu (Kemal Atatürk'ün Ölümü; Hükümetin Türk Halkına Hitabı)

U:

YUGOSLOVENSKİ LİST; 21, 266 (11.11.1938), na str. 1.

136. İsmet İneni-predsednik republike Turske: Priprema za Pogreb Kemala Ataturka (Türkiye Cumhuriyeti'nin Başkanı İsmet İnönü; Atatürk'ün Cenaze Töreniyle İlgili Hazırlıklar).

$\mathrm{U}:$

YUGOSLOVENSKİ LIST; 21, 276 (12.11.1938), na str. 1. 
137. Çestitka Kneza Namyestnika, İ. İnönü: Yugoslovenska delegatsiya na sahrani Kemala (Prens Vekili'den İ. İnönü'ye Telgraf; Yugoslavya Heyeti Kemal'in Cenaze Töreninde).

U:

YUGOSLOVENSKİ LIST; 21, 268 (13.11.1938), na str. 1.

138. Kemal Ataturk ye umro. (Kemal Atatürk Vefat Etti)

$\mathrm{U:}$

YUGOSLOVENSKA POSTA; 2876 (11.11.1938), na str. 1.

139. Nakon smrti otsa Otatzbine: Ko çe saçuvati Ataturkovu politiku i duhovnu baştinu: Misiya i program velike natsionalistiçke partiye u Turskoy (Devlet Atasının Ölümünden Sonra; Atatürk'ün Siyasi ve Manevi Zenginliğini Kim Koruyacak; Türkiye'deki Büyük Halk Partisi'nin Misyonu ve Programı).

U:

YUGOSLOVENSKA POŞTA; 10, 2878 (13.11.1938), na str.2.

140. Prenos tela Kemala Ataturka iz Tsarigrada u Ankaru izvrşite se sa veliçanstvenim posmrtnim poçastima: Turska jali svoga velikoga Şefa: İnostrana ştampa vrlo povolyno komentarişe izbor g. İnenia za predsednika Turske Republike (Kemal Atatürk'ün Naaşı İstanbul'dan Ankara'ya Muhteșem Bir Cenaze Töreniyle Uğurlanacak; Türkiye, Büyük Atası İçin Yas Tutuyor; Yabancı Basın, İnönü'nün Türkiye Cumhuriyeti Başkanı Seçilmesine Olumlu Yorumluyor).

U:

PRAVDA: 34, 12214 (13.11.1938), na str. 1.

141. Ankara tsvet Anatoliye (Ankara, Anadolu'nun Çiçeğidir)/M. Svetovski.

$\mathrm{U:}$

SMENA; 1, 4, (yuni/Haziran 1938), str. 243-246.

1939

142. Struktura danaşnye Turske (Türkiye'nin Bugünkü Yapısı)/ Manoylo Çuçkoviç. 
U:

YUJNI PREGLED; 13, 1 (yanuar/Ocak 1939), str. 29-35.

143. Gazi Kemal Atatürk.

U:

DIYYEÇL NOVI BEHAR: PROLOG "NOVOM BAHARU"; 7, 7, 14 (15.01.1939), na str. 29.

144. Pazliçnosti: Povodom smrti Kemala Ataturka, osnivaça Nove Turske (Farklılıklar; Yeni Türkiye'nin Kurucusu Kemal Atatürk'ün Ölümü Dolayısıyla).

U:

RATNIK; 55, 3-4 (yanuar/Ocak) str. 109-113.

145. Sivi vuk iz Ankara (Ankara'dan Bozkurtal I S-krakou; Prikaz "Kemal paşa" od H. Ts. Amstronga (H. Ts. Armstronga'nın "Kemal Paşa" Öyküsü).

RATNIK; 55, 4 (april/Nisan 1939) str. 135-140. Streichan.

146. Turska jene danas (Bugünkü Türk Kadını)/Gertrud Matschenz-

U:

SMENA; 2, 3-4 (mart-april/Mart-Nisan 1939), na str. 201.

147. Bulbuloviçevo delo o Kemalu i Turskoy (Kemal ve Türkiye Hakkındaki Bulbuloviç'in Çalışmasıı)/S.C.

U:

GAYRET, 20, 14 (detsembar/Aralık 1939), str. 259-260.

\section{1}

148. Politiçki pregled: Mecunarodni znaçay Turske u danaşnyem sukobu (Siyasi Yorum: Türkiye'nin Bugünkü Kargaşası) / M.V. Jeravjiç.

$\mathrm{U}:$

BRAZDA; 1,2 (februar/Şubat 1941), str. 110-112.

\section{3}

149. Rajanye nove Turske (Yeni Türkiye'nin Doğuşu)/D. Mrjenoviç $\mathrm{U}:$

TSRVENA ZVEZDA; 3,78 (20.10.1953), na str. 2 . 
$3,79(27.10 .1953)$, na str. 2 .

3,80 (3.11.1953), na str.2.

3,81 (10.11.1953), na str. 2 .

3, 83 (24.11.1953), na str. [6]

150. Trideset godina Turske Pepublike (Türkiye Cumhuriyeti Otuz Yaşında) / Zdravko Peçar

$\mathrm{U}$ :

BORBA; 18, 272 (29.10.1953), na str. 4.

151. Revolutsiya Kemala Ataturka u svyetlosti danaşnye Turske (Kemal Atatürk'ün Yaptığı İhtilâlin Günümüz Türkiye'sine Yankıları) Lyubo Radovanoviç

$\mathrm{U}$ :

OSLOBOCENYE; 11, 2233 (29-30.11.1953), na. str. 4.

152. Ataturk/Vasko Anastasov

$\mathrm{U:}$

NOVA MAKEDONIYA; 10, 2794 (10.11.1953).

\section{4}

153. Priyatelska Turska: Kemal Ataturk, otats danaşnye Turske (Kardeş Türkiye; Atatürk, Günümüzün Türkiye'nin Atasidır) / O. Miliçeviç

U:

BORBA; 19, 91 (17.04.1954), na str. 3-4.

154. Portreti naşih gostiyu-Celal Bayar: Sin zemlye sivoga vuka (Misafirlerimizin Portreleri; Celal Bayar, Bozkurt Toprağın Oğludur)/J. Stekiç

$\mathrm{U}:$

NEDELYNE INFORMATIVNE NOVINE; 4, 191 (29.08.1954), na str. 1 .

$$
1960 \text { (z.z.)* }
$$

155. Bio sam Lenyinov poslanik u Turskoy: Seçanye na Kemala Ataturka (Lenin'in Türkiye'deki Elçisiydim; Kemal Atatürk'ü Hatırlama) /S. Aralov.

$\mathrm{U}:$

* Çevirmenin eklemesidir 
NiN; 10, 495 (3.07.1960); İzbor dokumenta i çlanaka iz svetske ştampe (Dünya Basınından Seçilmiş Belge ve Makaleler); 1, 27, (3.07.1960), na str. 2.

156. İstoriyski govor Gazi Mustafe Kemala Ataturka (Gazi Mustafa Kemal Atatürk'ün Tarihi Nutku); Preveo (çeviren) İsmayil Hakki Çauşeviç

U:

GLASNIK VRHOVNOG İSLAMSKOG STARYEŞINSTTVA; 11, 13 (yan.-mart/Ocak-Mart 1960), str. 310-312.

\section{2}

157. Mladoturskata revolutsiya od 1908 i ulagata na Kemal Ataturk (1908 Yılındaki Yön Türk İhtilâli ve Kemal Atatürk'ün Rolü)/Glasnek Yohanes; Prevod (çeviren) Margarita Aleksovska

U:

ISTORIYA; 8, 2 (1972), str. 65-79.

\section{3}

158. 50 godina na Republikata Turtsiya (Türkiye Cumhuriyeti'nin 50. Yıll Dönümü)/Hasan Vefki

U:

NOVA MAKEDONIYA;

29,9589 (1.10.1973).

29,9590 (2.10.1973).

29, 9591 (3.10.1973).

29,9592 (4.10.1973).

29.9593 (5.10.1973).

1980

159. Turska se vraça Ataturku (Türkiye, Atatürk'e Dönüyor) Darko Ribnikar

U: 
POLITIKIKA;

77,24093 (31.10.1980), na str. 21.

77,24094 (1.11.1980), na str. 23.

77,24095 (2.11.1980), na str. 19.

77,24096 (3.11.1980). na str. 21.

77,24097 (4.11.1980), na str. 21.

77,24098 (5.11.1980), na str. 21.

77,24099 (6.11.1980), na str. 23.

77,24100 (7.11.1980), na str. 21 .

77,24101 (8:11.1980), na str. 23.

77,24102 (9.11.1980), na str. 17.

77,24103 (10.11.1980), na str 21 .

77,24104 (11.11.1980), na str 21.

77,24105 (12.11.1980), na str. 21.

77,24106 (13.11.1980), na str. 23.

77,24107 (14.11.1980), na str. 21.

77,24108 (15.11.1980), na str. 23.

77,24109 (16.11.1980), na str. 17.

77,24110 (17.11.1980), na str. 21 .

77,24111 (18.11.1980), na str. 21.

77,24112 (19.11.1980), na str. 21 .

77,24113 (20.11.1980), na str. 23.

77,24114 (21.11.1980), na str. 21 .

77,24115 (22.11.1980), na str. 23.

77,24116 (23.11.1980), na.str. 21 .

77,24117 (24.11.1980), na str. 21.

77,24118 (25.11.1980), na str. 21 .

77,24119 (26.11.1980), na str. 21.

77,24120 (27.11.1980), na str. 21. 
1981

160. Stogodişnitsa Ataturka (Atatürk'ün Yüzüncü Yıl Dönümü)/ Türkkaya Ataöv

U:

MECUNARODNA POLITIKA; 32.756(1981), str. 23-24.

1982 (z. z.)

161. Mustafa Kemal Ataturk-tvorats moderne Turske: Prvi buntovni koratsi (Mustafa Kemal Atatürk, Modern Türkiye'nin Kurucusudur; İlk İhtilâlciler)/Pripremila (hazırlayan) Danitsa Yakşiç

U:

OSLOBOCENYE; 39, 12302 (23.091982), na str. 8.

162. Mustafa Kemal Ataturk-tvorets moderne Turske: Povratak u Solun (Mustafa Kemal Atatürk, Modern Türkiye'nin Kurucusudur; Selyanik'e Dönüş)/Pripremila (hazırlayan) Danitsa Yakşiç

U:

OSLOBOCENYE; 39, 12303 (24.09.1982), na str. 8.

163. Mustafa Kemal Ataturk-tvorats moderne Turske: Turska Turtsima (Mustafa Kemal Atatürk, Modern Türkiye'nin Kurucusudur; Türkiye Türklerindir)/Pripremila (hazırlayan) Danitsa Yakşiç

U:

OSLOBOCYENYE; 39, 12305 (25.09.1982), na str. 10.

164. Mustafa Kemal Ataturk-tvorats moderne Tuske: zapostavlyeni pobyednik (Mustafa Kemal Atatürk, Türkiye'nin Modern Kurucusudur; Ihmal Edilen Bir Kahraman)/Pripremila (hazırlayan) Danitsa Yakşiç

U:

OSLOBOCENYE; 39, 12306 (26.09.1982), na str. 12.

165. Mustafa Kemal Ataturk-tvorats moderne Turske: Raspad Osmanliyskog tsarstva (Mustafa Kemal Atatürk, Modern Türkiye'nin Kurucusudur; Osmanlı İmparatorluğu'nun Çöküşü)/Pripremila (hazırlayan) Danitsa Yakşiç 
U:

OSLOBOCENYE; 39, 12307 (27.09.1982), na str. 6.

166. Mustafa Kemal Ataturk-tvorats moderne Turske: U slujbi naroda (Mustafa Kemal Atatürk, Modern Türkiye'nin Kurucusudur; Halkın Hizmetinde)/Pripremila (hazırlayan) Danitsa Yakşiç

$\mathrm{U}$ :

OSLOBOCENYA; 38, 12308 (28.09.1982), na str. 10.

167. Mustafa Kemal Ataturk-tvorats moderne Turske: Osuden na smrt (Mustafa Kemal Atatürk, modern Türkiye'nin Kurucusudur; Ölüme Mahkum Edilen)/Pripremila (hazırlayan) Danitsa Yakşiç

U:

OSVOBOCENYE, 38, 12309 (29.09.1982), na str. 10.

168. Mustafa Kemal Atatürk-tvorats moderne Turske: Sodbonosna bitka (Mustafa Kemal Atatürk Modern Türkiye'nin Kurucusudur; Tarihi Bir Savaş)/Pripremila (hazırlayan) Danitsa Yakşiç

$\mathrm{U:}$

OSVOBOCENYE; 38, 123010 (30.09.1982), na str. 10.

169. Mustafa Kemal Ataturk-tvorats moderne Turske: Borba za republiku (Mustafa Kemal Atatürk, Modern Türkiye'nin Kurucusudur, Cumhuriyet İçin Mücadele)/Pripremila (hazırlayan) Danitsa Yakşiç

U:

OSVOBOCENYE; 38, 123011 (1.10.1982), na str. 10.

170. Mustafa Kemal Atatürk-tvorats moderne Turske: Proglaşenya Republike (Mustafa Kemal Atatürk, Modern Türkiye'nin Kurucusudur; Cumhuriyetin İlânı)/Pripremila (Hazırlayan) Danitsa Yakşiç

$\mathrm{U}:$

OSVOBOCENYE; 38, 123012 (2.10.1982), na str. 10.

171. Mustafa Kemal Atatürk-tvorats moderne Turske: Provocenye reformi (Mustafa Kemal Atatürk, Modern Türkiye'nin Kurucusudur; Reformların Uygulanması)/Pripremila (hazırlayan) Danitsa Yakşiç 
$\mathrm{U}:$

OSLOBOCENYE; 39, 123013 (3.10.1982), na str. 9.

172. Mustafa Kemal Ataturk-tvorats moderne Turske: Otsvaren tsily (Mustafa Kemal Atatürk, Modern Türkiye'nin Kurucusudur; Gerçekleşen Hedef)/Pripremila (hazırlayan) Danitsa Yakşiç

U:

OSLOBOCENYE; 39, 123014 (4.10.1982), na str. 6.

\section{4}

173. Şesdeset godina Republike Turske (Türkiye Cumhuriyeti'nin Altmışıncı Yı1 Dönümü)/Mustafa Resuloviç

$\mathrm{U}:$

PREGLED 74,5 (1984), str. 611-623.

\section{MALAR}

3. ANSIKLOPEDI VE SÖZLÜKLERDEN SEÇILMIŞ ÇALIŞ-

1. Ilustrovani leksion, (Resimli Sözlük), Begorad, İzdanye ilustrovanog lista Nedelya, 1933.

Kemal Paşa Mustafa; na str. 242.

2. Sveznanye. Opşti entsiklopedişki leksikon (Genel Ansiklopedik Sözlüğü), Beograd, Nauçno delo, 1937, Prva knyiga.

Kemal Paşa, na str. 1035.

\section{LONÇAREVIÇ, Duşan A.}

Anali Politiçkih-kulturnih i privrednih dogecaya: (Siyasi, Kültür ve Ziraat Olayların Incelemesi) Entsiklopediya yavnog jivota u reçi i slitsi, (Toplumun Resimli ve Sözlü Ansiklopedisi) Beograd, Ştampariya Minerva, 1938,768 sayfa +8 sayfa ilustr.

Atatürk K. s. 93, 101-106, 289, 309, 351, 352, 656, 658-659, 665, $670,672,679,694,698,704,743$.

4. Mala entsiklopediya Prosveta: Opşta entsiklopediya (Küçük Eğitim Ansiklopedisi; Genel Ansiklopedi), I-II, Beograd, Prosveta, 1959, 1. t.*

Kemal Atatürk; Gazi -Mustafa Kemal-Paşa Ataturk, na str. 423.

* Cilt 
5. Voyna ensiklopediya, (Askeri Ansiklopedi) Beograd, İzdaniye redaksiye voyne ensiklopediye $1961,4 \mathrm{t}$.

Mustafa Kemal Atatürk, na str.423.

6. Ensikpolediyski leksikon mozaik znanya (Mozaik Bilgisinin Ansiklopedik Sözlüğui), İstoriya, Beograd, Unterpress, 1970, 5 t.

Atatürk, Mustafa Kemal-Paşa, na str. 45.

7. Mala sploşna Ensiklopediya, (Küçük Cep Ansiklopedisi) Lyublyana, Beograd, Drjavna zalojba Slovene, Prosveta, 1973

Kemal Atatur, Mustafa

8. Ensiklopediya Leksikografskog zavoda, (Leksikografik Kurumunun Ansiklopedisi) Zagreb, İzdaniye i naklada Leksikografskog zavoda FNRY,* 1955, t. 1 .

Atatürk, Mustafa Kemal- Paşa, s. 261-262.**

* Yugoslavya Federal Halk Cumhuriyeti

** Cevirmenin Notu: "Bibliyografik Ek"in 1. bölümü 23 Sirpca $(1,2,6,7,8-12,14$ 18, 20-22, 24, 27-31), 5 Hırvatça $(3,5,13,19,25), 2$ Boşnakça $(23,26), 1$ Makedonca (32), 2. bölümü 144 Sirpça $(1-3,6-10,12,13,18,23-25,27,29,30,32-57,59,60,62,63$, $65,67-69,71,73-88,90-110,112-130,132-135,138-146,148-151,153-156,159-173)$, 17 Boşnakça $(4,5,14,16,17,19-22,26,28,31,58,64,66,72,147), 8$ Hırvatça $(11,15$, $61,89,111,131,136,137), 3$ Makedonca $(152,157,158)$, 1 Slovence $(70), 3$. bölümü de 6 Sırpça (1-6), 1 Hırvatça (8) ve 1 Slovence (7) çalışma içermektedir. 


\section{ATATÜRK DÖNEMINDE TARIM POLITTIKASI}

Prof. Dr. Vecdet ERKUN

Bir ülke düşünün ki nüfusunun $\% 80$ 'i okuma, yazma bilmiyor, $\%$ 90 ' 1 çiftçi, $780.000 \mathrm{~km}^{2}$ yerde 13.000 .000 kişi barınıyor ve düşünün ki bu ülke Balkan, Çanakkale, I. Dünya Savaşı'ndan çıkmış yorgun bitkin ve bu yönleri ile bir çok ihtiyaçlar içinde kıvranan bir ülke... Böyle bir ülkenin kalkınması bir çok engelleri aşması, gelişmiş ülkelerce hiç beklenmiyor. Bu ülkenin başında da ilkeleri belli Türk milletinin özünde ilerleme aşkı olduğunu bilen insanlar var. Bu insanlar bir avuç aydın da olsalar milletiyle bütünleşme yollarını bilen insanlar, bu insanlar Türk hudut boylarında ve yurt içindeki alevleri söndürmeye ahdetmiş insanlardır. İște bu aydınların içinde gençliğinden beri Türkiye halkının daha iyi bir yaşama kavuşması için ilkeleri zihninde biriktirmiş biri var. $\mathrm{O}$ da son yüzyılların başka ulusların tarihinde yer almamış bir büyük insan, yüce Atatürk. Evet, yüce Atatürk ve arkadaşlan bu ümidini yitirmiş, yorgun halk kitlesi önünde yurtsever insanlar olarak yaptıkları çalışmalarda bir takım ulusal amaçlar belirlemişlerdir. Bu amaçları genel anlamda açıkladıktan sonra Tarım alanındaki politikanın temelleri üzerinde durmamızda yarar görüyorum.

Yerli ve yabancı siyaset bilimi araştırıcılarının yaptıkları araştırmalarla, vardıkları sonuçlara göre, Atatürk ilkeleri açık bir dünya görüşüdür. Bu görüş pozitif, hürriyetçi, bağımsız, bilime dayalı bir nitelik taşır. Bu ilkeler ışığında Atatürk inkılaplarının güç kaynağı bilime, gerçekçiliğe dayanır. Akılcı, laik, halkçı, milliyetçi ve Cumhuriyet prensiplerinin sentezinden oluşmuş, dünya görüşünde batılılaşmayı ana amaç olarak seçmiş ye bu yolda gelişmeye inanmıştır. Bu bakımdan bir çok yazara göre Atatürkçülük, realist, pozitivist bir düşünce sistemidir. Diğer yandan, Atatürk İstiklal Savaşı başlamadan, Samsun'a ulusal egemenlik ilkesine erişmek amacında olduğu için çıkmış özgür bir toplumun varlığını öngörmüş olması nedeniyle demokratik temelli akıldan ve ilimden kuvvet alan sürekli bir dinamizmi amaçlamıștır. Temelde, Atatürk ilkeleri insanoğluna ne yeryüzü cenneti vadederek bilimle çelişkiye düşen ve ne de insan aklını ve vicdanını zincire vuran sistemler, ideolojiler içerisinde yer alır. Bu sistemler tenkide açık değildir. Atatürkçülük tartışmaya ve tenkide açık ve yalnız kendi ekseni etrafında dönen kapalı bir görüse (Fanatik dini rejimler, komünizm, faşizm) bağlı şartlanmış bir görüş tarzı değil modern 
çağın açık, belirli ve özgür düşünceler sentezi, yani dünya görüşü olması onun tükenmez güç kaynağı ve güven verici sağlam bir yaşam kaynağıdir.

O halde Atatürkçülük ve o dönem kısaca ulusal egemenlik bakımından siyasi, sosyal, hukuki ekonomik ve külttürel alanların temelini millete dayalı bir açıdan görür. Özellikle ekonomik görüs bakımından da uygulayıcı nitelikte, dürüst, dünyada çağın gelişme düżeylerine göre hareket eden, özel teşebbüsün bilgi ve sermaye birikimi olmadığı için devlet önderliğinde özel teşebbüsünün gelişmesini öngören bağlar üzerine oturtulmuştur. (Kurulan kamu kuruluşları gibi) Bu atılımın amacı, geri kalmış bir toplumu çağdaş bir düzeye ulaştıran aynı zamanda ulusal ekonomi bakımından özgün ve süratle milletin yaşam düzeyini yükseltmek için çalışan çok çalışan bir atılımdır. Evet çalışmak geleneklerimize çok uyar. Bunu tek tümce ile ifade etmek istersek (Atatürkçülük Türkiye'nin çağdaş medeniyet düzeyine erişmesini Atatürk'ün başlattı̆g inkılapların yürütülmesiyle mümkün olduğunu şart olarak kabul eden yoldur).

Atatürk Döneminde Tarım Politikasının esasları; belirlemeye çalıștığım çağdaş ilkelere dayandırılmıştır. Bununla ilgili olarak Atatürk tarafından söylenmiş bazı deyişlere burada yer vermek istiyorum.

- "Türkiye'nin sahibi hakikisi ve efendisi hakiki müstahsil olan köylüdür."

- "Ulusal eknominin temeli ziraattir." (1.11.1923)

- "Gerçek fütuhat, yalnız kılıçla yapılan değil, sapanla yapılandır." (16.03.1923)

- "Kılı̧ ve sapan, bu iki fatihten birincisi ikincisine daime yenildi." (16.03.1923)

- "Tam bağımsızlık ancak ekonomik bağımsızlıkla mümkündür."

- "Zenginlik ve onun doğal sonucu olan bolluk, rahatlık ve mutluluk yalnız ve ancak çalışanların hakkıdır."

Daha pek çok böyle deyişler var. Bunlar politikaya yön verici sözlerdir. Böylece öyle bir politika ortaya konmuştur ki bu politikanın amacı dengeli, dinamik, sağlıklı ve sağlam temellere oturtulan kalkınma esaslarını ülke çapında uygulamaktır. Bu politika özellikle Tarım alanında teknik ve idari alanda bir pakettir. Çünkü yalnız uygulama ile ilgili teknikler hakkında değil, fakat bu uygulamraların gerçekleştirilmesi için kurumlaşma ile ilgili yasaların çıkarılması da daima göz önünde tutulmuştur. Bu hususta o kadar çok yararlı adımlar atılmış̧ır ki bunların hepsine burada yer vermek mümkün olmadığı için bazı örneklere değineceğim. 
Örneğin, 2 Aralık 1925 yılında çıkarılan 682 sayılı yasa ile ziraatın gelişmesi için; her çeşit filan ve tohumların bedelsiz dağıtımı ve Devletin yönetiminde fidanlık kurulması çiftçinin eğitimi ve verimin artırılması için bedelsiz olarak verilmesi hakkındaki yasadır. Bu yasa çiftçi eğitimi metodlarından olan demonstrasyonların yapılması için temel teknik bir uygulamadır. Marşal yardımı başladığı zaman Amerikan tarım uzmanları böyle bir yasanın varoluşuna şaşmışlardır. Çünkü Amerika Birleşik Devletlerinde Tarım alanında bir yeniliği çiftçilere öğretmek için demonstrasyonlar yapılması temel çiftçi eğitimi metodu olarak bilinir.

Diğer taraftan sabit ve döner sermaye yasaları ile Tarım kuruluşlanna sermaye verilmesi sağlanmıştır (26 Ocak 1925) Bu yasa, devlet eliyle çiftçilere teknik çalışma sonuçlarının gösterilmesi, sermaye, yatırım ve karlılık kavramlarının öğretilmesi yolunda bir düzenlemedir.

Elbette o dönemde köylerin idaresi, gelişmesi sorunlarının çözülmesi, elbirliği, güçbirliği ile köyün kalkınması da dikkate alınmış ve 442 sayılı köy kanunu çıkarılmıştır. Ayrıca verimin artırlması için ekolojik koşullara uygun olarak yüksek verimli tohumlukların gümrük resminden muaf olması yönünde bir yasa çıkarılmıştır. (24 Mayıs 1930)

Bu çalışmalara paralel olarak Türkiye'nin değişik bölgelerinde Tohum Islah istasyonlan kurulmuştur. Halen bu istasyonlar Zirai Araştır- ma Enstitüleri halinde çalışmaktadırlar. Benim yaptığım araştırmalara göre özellikle Anadolu'da yetişen buğdaygil yem bitkilerinin tohum tutma (Seed Seting) oranları elverişli ekolojik koşullar nedeni ile diğer ülkelerden çok fazladır. Bu bizim bir çok tohum üretme alanında dünyada sayılı ülkelerden olabileceğimizin bilimsel kanıtıdır.

Atatürk döneminde ayrıca Tarımın makineleşmesine de önem verilmiştir. Atatürk bizzat kendi kurduğu orman çiftliğinde modern Ziraat alet ve makinelerinin kullandırılmasına önem vermiştir..

Tarım alanında atılımlar yapılırken elbette Tarım Teşkilatının çağdaş ülkelerdeki gibi organize edilmesi gereği de vardır. Böylece Ziraat Vekaleti Teşkiline dair 1910 sayılı kanun, 29 Aralık 1931 yılında çıkmıştır. Sonradan ilaveler yapılmıştır.

Veteriner Teşkilatı, Orman Teşkilatı bu dönemde çağdaş bir düzene sokulmuştur. 4 Haziran 1935 yılìnda çıkan Ziraat Vekaleti Vazife ve Teşkilat kanununda veteriner ve 1937 yılında çıkan 3116 sayılı Orman kanunu ve ilaveleriyle orman teşkilatı kurulmuştur. Veteriner yasalarının önemlilerinden Hayvan Sağlık ve Zabıtası Kanunu 3 Mayıs 1928 de çıkmıştır. Bütün bu yasalar henüz yürürlüktedir. Ayrıca İşletmelere Döner Sermaye verilmesi (1934) sağlanmıştır. 
Tarım Satış ve Kredi Kooperatiflerinin kuruluşu (1935), Pamuk Islah, Çeltik ekimi Ziraat Bankası'nın kuruluşu, Devlet Mețeoroloji İşleri Umum Müdürlüğü'nünün kuruluşu 1937 yılındadır. Ayrıca 1933 yılında Yüksek Ziraat Enstitüsü kurulmuş ve sonra bu Enstitüden Ankara Universitesi Ziraat ve Veteriner Fakülteleri doğmuştur. Atatürk Orman Çiftliği kuruluşunda belirttiğim gibi modern Ziraat alet ve makineleri burada kullanılmıştır. (Ziraat Müzesi) Ayrıca yine bu dönemde önemli atılım olarak SSeker Pancarı ekimi ile Şeker Fabrikalarının kuruluşu büyük bir eserdir. Âşar'da bu dönemde kaldırılmıştır.

Görülmektedir ki savaştan çıkmış, yorgun kısıtlı imkanları olan Türk çiftçisinin kısa zamanda arzulanan üretici bir toplum haline gelmesi için en ileri çağdas yaptırımlara yer verilmiştir. Bu yasa ve kuruluşlarla, çiftçi eğitimi, modern tarım işletmeleri kurulması, bitki islahı kredi sağlanması, değerlendirme, kurumlaşma çalışmaları bir paket halinde ortaya konmuştur. Kısaca Atatürk döneminde Tarım Politikasında değişmez temeller atılmıştır. Bence Tarım Politikası, kültürü Cumhuriyet yaşamına yerleştirilmiştir.

Ben Birleşmiş Milletler Gıda ve Tarım Teşkilati'nda (FAO) çahışırken (1966) ve sonraları Dünya Bankası'nın Tarım Kredileri çalışmalarına katılan bir kişi olarak şunu belirtmek istiyorum. Atatürk'ün uyguladığı bu politika halen gelişmemiş bir ülkenin tarımsal kalkınması için Dünya Bankası ve Birleşmiş Milletler Gıda ve Tarım Teşkilatı'nın hazırladıkları rapor ve projelerde yukarıda belirttiğim konular yer almıştır.

Demek ki Atatürk döneminin Tarım Politikası diğer ülkelere ve uluslararası kurumlara da ışı tutmuştur.

Atatürk bu günkü Türkiye'yi büyük bir düşman topluluğuna karşı tek başına müdafaa etti. Göçmüş Osmanlı İmparatorluğu'nun yıkıntıları arasında kalmış kahraman bir milletin elinden tuttu. Büyük Türk milletine atalarından gelen Milli Şuur ve cesaretini, güvenini iade etti. Atatürk, düşmanları kimsenin inanmayacağı bir şekilde silkeledi yendi ve denize döktï. Türk insanınının milli bağımsızlığına kavuşturarak bu günü bizlere bir özgür ve dünya düzeyindeki şeref ve şanlarla dolu bir millet olarak çağdaş, laik, gelişmiş bir Türkiye yaratma hazzını azmini verdi. $O$ büyük insanı tanımak, görmek şerefine nail oldum. Mütevazi, kararlı, insan seven şefkatli, yardımsever, büyük bir halk lideri idi.

"Yurtta Sulh, Cihanda Sulh" sözü onun yalnız barışsever insan olduğunu değil, aym zamanda insan sever, yüksek ahlaklı bir kişi olduğunu göstermektedir. Rahmetli babamdan öğrendiğime göre Kuvayi Milliyecilerin çoğu mütevazi, şahsi menfaat gütmeyen, insan sever, halkın içinde olmaktan mutluluk duyan, amaçlan Türk yurdunu geliştirmek olan insanlar topluluğu idi. Bu bakımdan Atatürk'ün ve onun arkadaşlarının pek çok zorluklanı aşarak bizi bu günlere getiren feragatlı çalışmalarını genç kuşaklara anlatmalıyız. 
Sonuç olarak, Atatürk dönemindeki tarım politikası,

\section{1- Çiftçilerin eğitimi}

2- Modern ziraat alet ve makinalarının kullanımı

3- Kurumlaşma ve döner sermaye işletmelerinin kurulması

4- Kredilendirme

5- Değerlendirme gibi tarımsal kalkınmada ana tedbirleri getirmiştir.

Evet Sayın dinleyiciler, kolay değildir Türk olmak, kolay değildir Atatürk ilkeleri yolunda yürümek, ama Türk olmak şerefi de o kadar büyüktür. Olgun bir insan vatandaş olmak için gerçekleri araştırmaktan korkmamalıyız. Geçici hevesler yerine üstün yurtseverlik gereğine dayalı bir amaç için çaba sarfetmeliyiz.

Vatana hizmet yolunda büyük başarılara erişmek için yaptığımız yeminlere verdiğimiz sözlere sadık kalarak, kendi çıkarlarımızı düşünmeden fedakar Türk insanları olarak çalışmalı çalışmalıyız.

\section{NE MUTLU TÜRKÜM DIYYENE}

\section{ATATÜRK VE TARIMLA ILGILI BİR ANI}

Bu anı aynı zamanda "Türkiye'nin sahibi hakikisi ve efendisi, hakiki müstahsil olan köylüdür" deyişi ile de ilgilidir.

İşte bu talimat ve bu basit gibi görünen olay tarım politikamızda daha esaslı adımlar atılmasına sebep olduğuna şüphe yoktur.

Y1l 1936, Atatürk İstanbul'da Florya köşkündedir. Mevsimlerden sonbahar. Atatürk'ün köşkte halkla temas edememekten ötürü canı sıkılmaktadır. Selanik günlerinden dostu Nuri Conker'e köşkten gizlice kaçmayı teklif eder. Nuri Conker özel bir araba bularak ve Atatürk de kıyafetini değiştirerek köşkün kapısında bekleyen özel araba ile Çekmece'ye doğru ilerlemeye başlarlar. Atatürk neşelidir. Refakatte kimse yoktur. Birden Atatürk'ün gözleri çift süren bir köylüye takıldı. Arabayı durdurdu. Köylünün yanına gitti, çiftin bir yanında öküz, bir yanında merkep vardı. Ulu önder köylü ile konuşmaya başladı. Köylü onu tanımamıştır. Atatürk çifte öküz yerine neden merkep koştuğunu sordu. Köylü vergi memurlarının sattığını bildirdi. Atatürk muhtar ve kaymakama neden şikayet etmediğini sordu, öküzün satılmaması gerektiğini bildirdi. Köylü "onlar bilmez olurlar mı burada kuş bile uçmaz, şimdi Atatürkümüz var başımızda" der. Atatürk, Valiye ve Başvekil İsmet Paşa'ya derdini anlatmasını söyledi. Köylü onlara derdini işittiremiyeceğini bildirdi. Nihayet 
Mustafa Kemal Paşa'ya derdini anlatmasını tavsiye eden Atatürk'e köylü "O işinden gücünden başını kaldırıp bizim öküzün arkasından mı seyirtecek, sen gönlünü rahat tut beyim, biz işimizi koca oğlanla görürüz tasa etme" der.

Atatürk, Nuri Bey'le birlikte köşke döner, yaverine İstanbul'daki Bakan Milletvekili ve Başvekil İsmet Paşa'yı, İstanbul Valisini çağırması emrini verir. Nuri Bey'e de köylü Halil Áğa'yı köşke getirmesini bildirir. Nuri Bey Halil Ağa'yı bir çok uğraşıdan sonra kendisi ile görüşen zatın zengin olduğunu öküz vereceğini vaadini de yaparak, karısının ısranı üzerine, köşke getirir. Sofrada 25 kişi vardır. Atatürk bir ara hazır bulunanlara "Bu akşam soframıza efendimiz gelecek" der. Herkes şaşırmışır, kimdir bu efendimiz? Atatürk Başyavere buyursun talimatını verir. Köylü Halil Ağa girmemekte diretmektedir. Gevezeliğinin cezasını çektiğine inanır, Nuri Bey köylünün koluna girerek salondan içeri sokar.

Atatürk, Halil Ağa'ya hoş geldin dedikten sonra "İşte beklediğimiz efendimiz" diye onu tanitır. Atatürk orada bulunanlar huzurunda tarlada konuşulanlar ve Halil Ağa'nın herkes hakkında ne dediğini bir bir köylünün kendi ağzından tekrar ettirir. Halil Ağa ikramdan sonra ayrılır. Atatürk hazır bulunanlara hitaben "Halil Ağa'nın öküzünü satıp üretimi aksatan kanunu, ya biz yaptık, yà da bizim yaptığımız kanun yanlış yorumlanarak uygulama yapılıyor. Böyle bir kanun yaptıksa memleket çıkarlarına aykırıdır. Nasıl yaparız. Eğer yaptığımız kanun böyle yorumlanıyorsa Hükümet nasıl bir yönetim içindedir? Unutmayın ki olay İstanbul'da geçiyor. Acaba diğer yörelerde neler oluyor? "Biçiminde konuşarak" Biz Cumhuriyetí süs olsun diye kurmadık. Halktan yana bir idare kurmak için yaptık. Hükümetin müfettişlerini, valileri, kaymakamları var. Bunların Halil Ağa'nın öküzünü satmanın ne demek olduğunu bilmeleri gerekir. Bir parti örgütümüz var, halkın içinde dirsek dirseğe yaşamaları gerekli, onlarda böyle bir uygulamadan söz etmiyorlar, ne demektir bu? Bizim halkla beraber ve halk için değil, halka rağmen bir sistem kurduğumuz sanılmaktadır. Asıl üzüldüğüm husus burası. Biz cumhuriyeti anlatamamışız beyler, bundan bu çıkıyor."

Atatürk, başta Başbakan İsmet Paşa olmak üzere hazır bulunanlara inkılapların yaşamasının bilinçli ve İnkılapçı kuşağın yetiştirilmesine bağlı olduğunu, Halil Ağaların başına gelenler Hükümet'e ve Büyük Millet Meclisi'ne ulaşmıyorsa tehlike olduğuna değinerek ilgililere gerekli talimatı verdi. 